\title{
Saldenioichthys remotus gen. et sp. nov. (Teleostei, Perciformes) and other acantho- morph remains from the Maastrichtian Saldeño Formation (Mendoza, Argentina)
}

\author{
Adriana López-Arbarello ${ }^{1}$, Gloria Arratia ${ }^{1}$ \& Maísa A. Tunik ${ }^{2}$
}

With 5 figures

\begin{abstract}
Some isolated acanthomorph remains and a new taxon of perciform fishes, Saldenioichthys remotus gen. et sp. nov., from the Maastrichtian Saldeño Formation of Mendoza province, Argentina, are described and their systematic affinities are discussed. The new taxon is represented by a single incomplete, but well preserved postcranial skeleton. With the exception of a fully developed neural spine on the second preural centrum, it agrees with the generalized skeletal features of basal percoids, in particular the generalized perciform caudal skeleton. The only other Mesozoic perciform skeletal remains known so far are Nardoichthys, from the upper Campanian-lower Maastrichtian of Nardo (Italy) and Eoserranus from the Upper Cretaceous Lameta Formation (India). Therefore, the new perciform taxon from the Saldeño Formation represents one of the oldest members of this group, and due to its peculiar combination of primitive and derived characters, it raises several questions regarding character evolution on this lineage.
\end{abstract}

Key words: Perciformes, Upper Cretaceous, Maastrichtian, South America, Argentina.

\section{Zusammenfassung}

Es werden einige isolierte Reste acanthomorpher Fische sowie ein neues Taxon der Perciformes, Saldenioichthys remotus gen. et sp. nov., aus dem Maastricht der Saldeño Formation in der Provinz Mendoza, Argentinien, werden beschrieben und ihre systematische Stellung wird diskutiert. Das neue Taxon ist durch ein einziges, unvollständiges, aber gut erhaltenes postkraniales Skelett repräsentiert. Mit Ausnahme eines vollständig ausgebildeten Dornfortsatzes auf dem ersten präuralen Zentrum stimmt es mit der generalisierten Skelettmorphologie basaler Percoiden überein, insbesondere mit dem generalisierten perciformen Caudal-Skelett. Die einzigen anderen Skelettreste von Perciformen aus dem Mesozoikum sind Nardoichthys aus dem Ober-Campan / Unter-Maastricht von Nardo, Italien, und Eoserranus aus der Oberkreide der Lameta Formation, Indien, und die Gruppe ist ansonsten praktisch nur aus känozoischen Sedimenten bekannt. Somit stellt das neue Taxon aus der Saldeño Formation einen der ältesten Nachweise dieser Gruppe dar, und wirft aufgrund seiner ungewöhnlichen Kombination primitiver und fortschrittlicher Merkmale einige Fragen zur Merkmalsevolution in dieser Linie auf.

Schlïisselwörter: Perciformes, Obere Kreide, Maastricht, Sütdamerika, Argentinien.

\section{Introduction}

Perciforms are well known from Tertiary sediments onwards, especially since Eocene times. Several isolated, usually fragmentary fish remains from different Cretaceous localities have been referred to Perciformes (e.g., Dartevelle \& Casier 1949, Estes 1964, Gayet et al. 1984, Cione 1987, Gayet \& Brito 1989, Gayet \& Meunier 1998, González-Riga 1999). However, the identification of perciform-like isolated osteological elements can only be done by their overall simi- larity with comparable elements of Recent forms. This procedure is problematic as noted in Wilson et al. (1992). In South America, a single pharyngeal jaw from the Maastrichtian Los Alamitos Formation (Río Negro, Argentina) was referred to Percoidei by comparison with similar tooth plates in sciaenids and carangids (Cione 1987). Similar tooth plates from the CampanianMaastrichtian Loncoche Formation (Mendoza, Argentina) were also referred to Percoidei by comparison with the material from the Los Alamitos Formation (González-Riga 1999). A

\footnotetext{
1 Institut für Paläontologie, Museum für Naturkunde der Humboldt Universität, Invalidenstrasse 43, D-10115 Berlin, Germany.

${ }^{2}$ Laboratorio de Tectónica Andina, Universidad de Buenos Aires. Current address: Cátedra de Sedimentología, Univ. Nac. Patag. "San Juan Bosco", Ciudad Universitaria, Kilómetro 4, Comodoro Rivadavia, Chubut (9000), Argentina.

Received March 2003, accepted July 2003
} 
single fin spine from the Upper Cretaceous Bauru Group (Uberaba, Minas Gerais, Brazil) was identified as belonging to a perciform by Gayet \& Brito (1989), but it should only be referred to as Euacanthopterygii since its only distinguishing character is a typical chain-link articulation base, which is also found in the dorsal fin of beryciforms (Johnson \& Patterson 1993). Finally, isolated cranial bones from Maastrichtian sediments of the El Molino Formation (Pajcha Pata, Bolivia) were referred to Latidae (one preopercle) and Percichthyidae (several preopercles and a hyomandibula) by overall similarity with Recent and Tertiary fossil members of these percoid families (Gayet \& Meunier 1998).

Prior to the present finding, Mesozoic articulated skeletal remains of perciform fishes have only been reported from the Maastrichtian Lameta Formation of India and the upper Campanian-lower Maastrichtian of Nardo in Italy (Patterson 1993). The material from India was described as Eoserranus hislopi Woodward (1908) within Serranidae (Percoidei). The Italian material consists of a very small, but rather complete specimen described as Nardoichthys francisci Sorbini \& Bannikov (1991) and left as Perciformes incertae sedis by the authors. Tertiary articulated perciform remains are, by far, much more abundant (e.g., Blot 1980, Grande 1984, Micklich 1985, 1988, 1989, 1990, Yabumoto \& Uyeno 1994, 2000, Murray 2000, 2002). In South America, articulated Tertiary perciform remains are known from Danian sediments of the $\mathrm{El}$ Molino Formation, Bolivia (Gayet \& Meunier 1998), the Eocene Casamayor Formation, Argentina (Schaeffer 1947), the Miocene Lonquimay and Cura-Mallín Formations, Chile (Chang et al. 1978, Arratia 1982, Rubilar 1994), Nirihuau and Collón Curá Formations, Argentina (Cione 1986), Anta Formation, Argentina (Casciotta \& Arratia 1993a), and Oligocene Tremembé Formation, Brazil (Woodward 1898, Arratia 1982, Ragonha 1982).

The new taxon described here is interpreted as a perciform (see below). It is one of the very few Mesozoic articulated perciform remains. Its holotype and only known specimen is described in the present paper, and its systematic position is discussed. We further describe and discuss other acanthomorph remains found in the same geological unit.

Although Perciformes have not yet been cladistically defined, and the group, as usually used, is probably not monophyletic, some progress has been made in our understanding of the phylogeny of percomorph fishes in recent years. Johnson \& Patterson (1993) found a basal dichotomy within Percomorpha, with one lineage leading to the Smegmamorpha (Synbranchiformes + Elassoma + Gasterosteiformes + Mugiloidei + Atherinomorpha) and the other one can be regarded as the lineage leading to the genus Perca. However, no characters support the monophyly of the Perciformes and their immediate relatives.

Institutional abreviation: CPBA-V, Cátedra de Paleontología de la Facultad de Ciencias Exactas y Naturales de la Universidad de Buenos Aires, Argentina; Colección de vertebrados.

\section{Geological settings}

The Saldeño Formation crops out in the high cordillera of Mendoza, Argentina. The outcrops are located in a continuous belt along the $69^{\circ} 45^{\prime} \mathrm{W}$ meridian from the Mesón de San Juan $\left(33^{\circ} 33^{\prime} \mathrm{S}\right)$ up to the Laguna del Diamante area $\left(34^{\circ} 06^{\prime} \mathrm{SL}\right.$ ) (Fig. 1). This unit is conformably overlain by the Pircala Formation; these two units constitute the Malargüe Group (Uliana \& Dellape 1981) in the Andean area and represent the filling of an Upper Cretaceous - Lower Tertiary foreland basin within the Neuquén and South Mendoza basin (Legarreta et al. 1989).

The Saldeño Fm. consists of three sections (Polanski 1957). The lower section is composed by $50 \mathrm{~m}$ of conglomerates and sandstones, which are not genetically related to the marine ingression (Tunik 2001). The middle and upper sections of the Saldeño Formation reach $200 \mathrm{~m}$ in thickness and they are composed by siltstones, sandstones, and limestones that record the Atlantic transgression during the Maastrichtian in the Andes (Tunik 2001). The middle section is composed of red to greenish laminated and massive siltstones and fine massive red sandstones with intercalations of tuffaceous beds. Light-colored limestones appear in the upper part of this section and become the predominant lithology in the upper section, which is made up of $100 \mathrm{~m}$ of yellowish calcareous beds. Massive and laminated mudstones and wackestones, massive packstones, oolitic and bioclastic grainstones, and stromatolites represent the predominant lithology of the calcareous section. Greenish sandstones and colourful tuffaceous beds are generally subordinate, but in some sections their presence can be significant. The tuffaceous beds gave the Saldeño Fm. conspicuous colourful intercalations of yellowish, violet and greenish tones. 


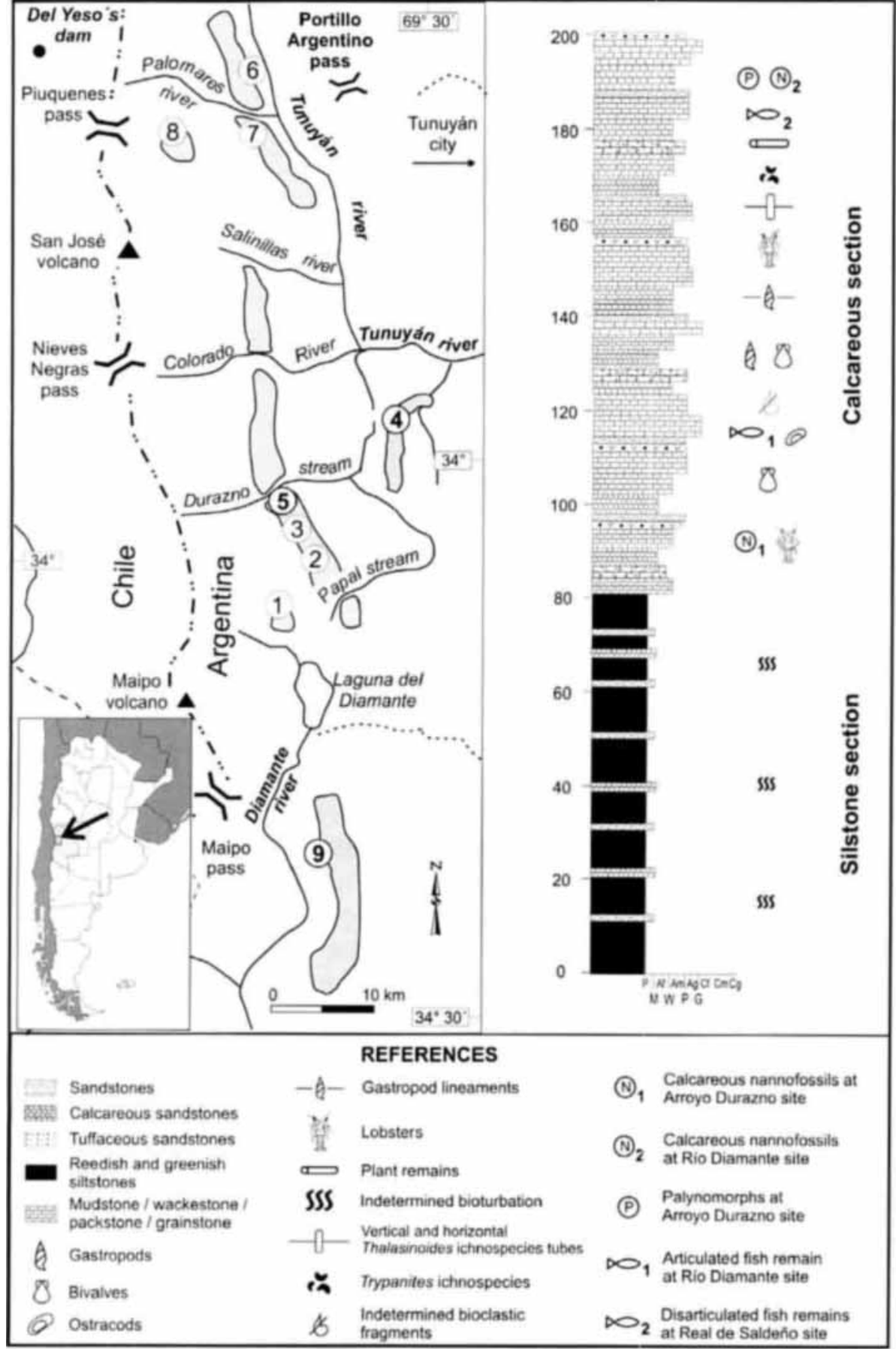

Fig. 1. Map and synthetic section of the middle and upper section of the Saldeño Formation in the Province of Mendoza, Argentina. The geological sites are: (1), Arroyo Duraznito, (2), Cajón de las Overas, (3), Quebrada Intermedia, (4), Real de Saldeño, (5), Arroyo Durazno, (6), Arroyo Peine, (8), Arroyo Atravesado, (8), Arroyo Morado, (9, Río Diamante. Paleontological sites mentioned in the text are in bold.
Environmental analyses were performed following the concept of Reading (1986), who defined a facies association as a group of facies that are genetically related. These environmental analyses were made after fieldwork and taking into account petrological and paleontological analyses previously made for the Saldeño Fm. (Tunik in press). Eleven lithofacies and two facies associations were recognized. They were deposited in a transitional environment from a muddy distal fluvial system to a restricted shallow marine environment with intervals deposited under brackish conditions and tidal influence.
Marine fossils, including bivalves, gastropods, fishes, and lobsters were discovered recently in the upper section of this unit (Tunik 2001, Tunik \& Concheyro 2002). The ostracods, pelecypods, gastropods, and crustaceans were found in one type of strata and unfortunately lack biostratigraphic value, but they helped to constrain the environmental reconstruction (Tunik in press). The upper levels of the Saldeño Fm. at the Arroyo Durazno site produced scarce palynomorphs with a regular conservation stage. The following pollen grains were identified: Equisetosporites notensis, Microachrydites antarcticus, 


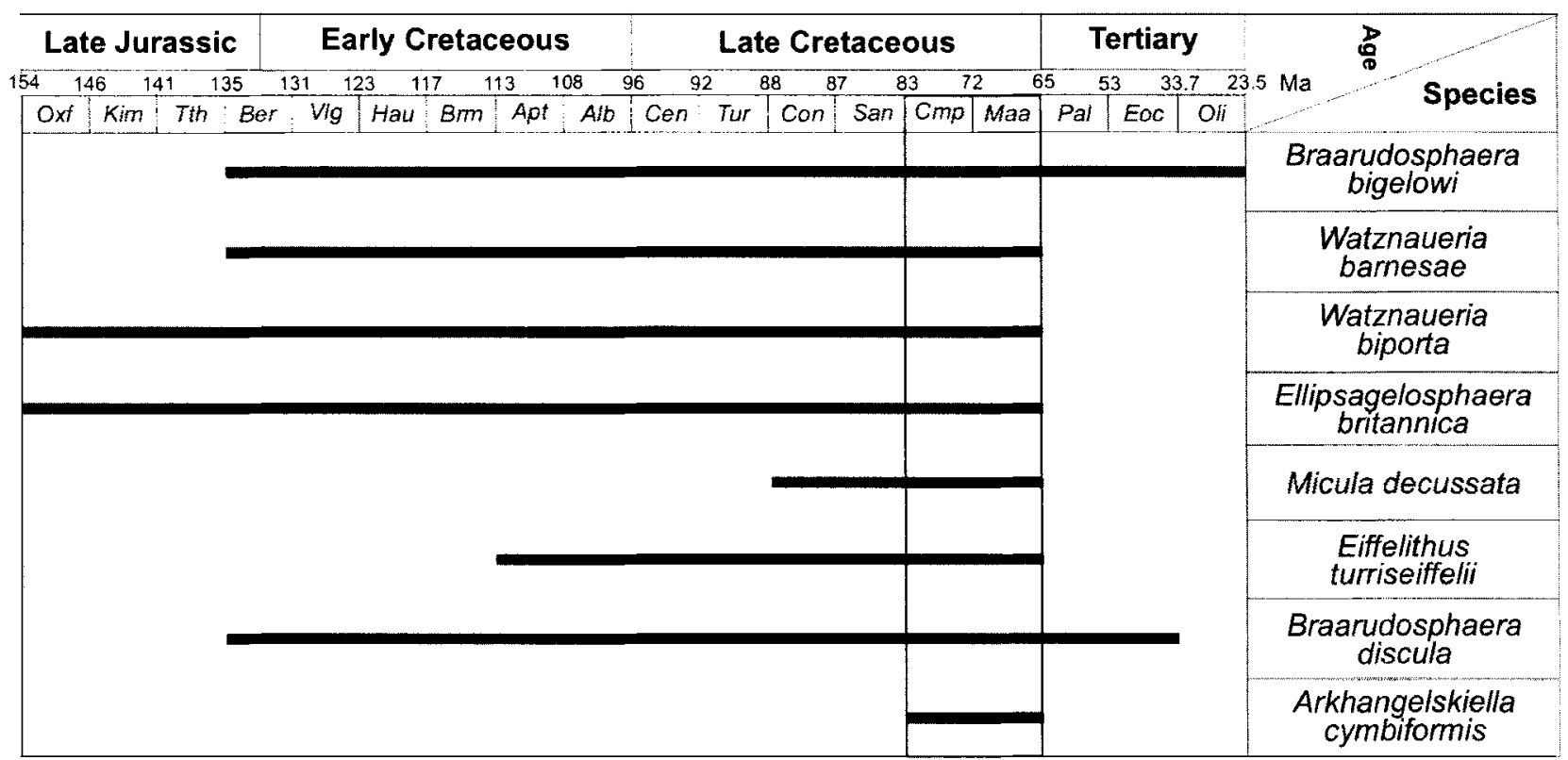

Fig. 2. Stratigraphic distribution of the calcareous nannofossils found in the Saldeño Formation (from Tunik 2001).

Periporopollenites sp. cf. $P$. polyoratus, Podocarpidites marwickii, Proteacidites sp., Retitricolpites sp., Tricolpites sp., and Pediastrum boryanum (Tunik \& Concheyro 2002). This palynological association indicates a minimum Maastrichtian age for the upper levels of the Saldeño Fm. Nannofossils were found in the Arroyo Durazno and Río Diamante sites. In the upper section of the Arroyo Durazno site the following nannofossil association was identified (Fig. 1): Braarudosphaera bigelowi (Berriasian-Oligocene), Watznaueria barnesae (Berriasian-Maastrichtian), Watznaueria biporta (Oxfordian-Maastrichtian), and Ellipsagelosphaera britannica (OxfordianMaastrichtian). On the other hand, in the middle section of the Río Diamante site, the nannofossil association is composed by Micula decussata (Coniacian-Maastrichtian), Eiffellithus turriseiffelii (Aptian-Maastrichtian), Braarudosphaera discula (Berriasian-Eocene), Arkhangelskiella cymbiformis (Campanian-Maastrichtian) and Ellipsagelosphaera britannica (Oxfordian-Maastrichtian) (Tunik \& Concheyro 2002). Therefore, the nannofossil associations, one of which (Arroyo Durazno site) appears above the fish bearing layers, indicate a Campanian-Maastrichtian age for the Saldeño Fm. (Fig. 2). Thus, considering all biostratigraphic evidence leads to a Maastrichtian age for the Saldeño Fm.

Further data support a Maastrichtian maximum age for the Saldeño Fm. Parras et al. (1998) and Parras \& Casadío (1999) found the K/T boundary within the Pircala Fm. in outcrops located further south in the Malargüe, Bardas
Blancas, and El Sosneado areas. Moreover, it is widely accepted that the marine ingressions during the Paleocene did not extend further north than $36^{\circ}$ SL (Bertels 1970, Legarreta et al. 1989, Casadío 1994, Malumián \& Caramés 1995).

The fish remains studied here were found in two different sections of the Saldeño Fm. (Fig. 1). The sequence at the Real de Saldeño site yielded only disarticulated and frequently fragmentary remains. On the other hand, the Río Diamante site produced a single, but articulated postcranial remain.

\section{Systematic paleontology}

Teleostei Müller, 1844

Euteleostei Greenwood et al., 1966

Acanthomorpha (sensu Johnson \& Patterson, 1993)

\section{Acanthomorpha incertae sedis}

\section{Undetermined acanthomorph}

Fig. 3

Referred material: CPBA-V-14098: Premaxillary bone, a piece of a possible infraorbital bone and other bone remains. CPBA-V-14096: Isolated ctenoid scales poorly preserved.

Horizon and locality: Oolitic packstones in outcrops of the Saldeño Formation (Maastrichtian) at the Real de Saldeño site (W: $69^{\circ} 31^{\prime}$, S: $\left.33^{\circ} 55^{\prime}\right)$ 

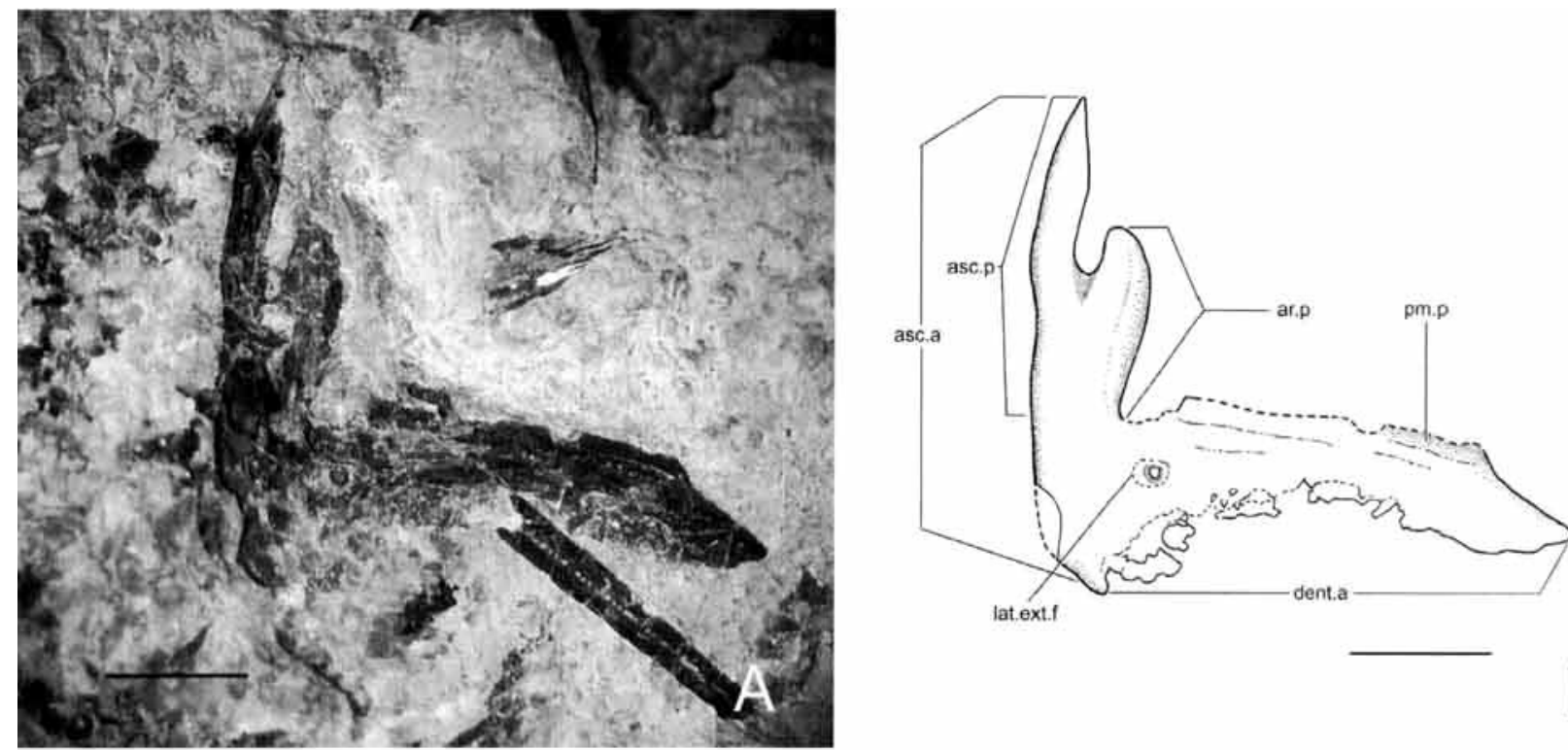

Fig. 3. Left premaxilla in lateral view (CPBA-V-14098). A. Photograph. B. Line drawing. Abbreviations: ar.p, articular process; asc.a, ascending arm; asc.p, ascending process; dent.a, dentigerous arm; lat.ext.f, lateral external foramen; pm.p, postmaxillary process. Scale bar equals $2 \mathrm{~mm}$.

Description: The heavily ossified premaxilla is exposed in lateral view and is partially broken. The bone consists of a dentigerous arm, an ascending arm formed by well developed ascending and articular processes, and probably a postmaxillary process. The dentigerous arm is slightly shorter than the ascending arm, about $96 \%$ of the length of the latter. The angle formed between the ascending and the dentigerous arms is 81 degrees, measured from the posteroventral tip to the anteroventral tip of the dentigerous arm, and to the dorsal tip of the ascending process. The ascending process is higher than the articular one, the height of the latter being $59 \%$ of the height of the first one. Both processes are joined at their bases, along $45 \%$ of the total height of the ascending process and $76 \%$ of the total height of the articular process, and they are then separated by a relatively narrow notch. In lateral view, the articular process is about the same width as the ascending process and its dorsal margin is rounded and slightly anterodorsally directed. In contrast, the dorsal tip of the ascending proces is acute and slightly posterodorsally directed. A relatively large foramen is found on the dentigerous arm, posteroventral to the articular process. The dorsal border of the dentigerous arm is broken, but a postmaxillary process was apparently present. The ventral margin of the dentigerous arm is markedly concave. The dentigerous area is mostly covered by the lateral bony layer of the premaxilla, so that only a few teeth are observed where the bone is broken.
The ctenoid scales are poorly preserved and do not permit a proper description of the cteni.

Remarks: There is not much information in the literature about the evolution of morphological changes in the premaxillae of acanthomorph fishes. However, the presence of a well developed ascending process on the premaxilla is considered to be a synapomorphy of Acanthomorpha (Stiassny 1986). The development of such a process is related to the evolution of the system of premaxillary protrusion, which is fully-realized in acanthopterygian fishes (Gosline 1980, 1981). Among acanthopterygians, a forward position of the articular process of the premaxilla, which is then joined together with the ascending process as is the case of the specimen studied here, was considered as a specialization in the protrusion system of small-mouthed fishes by Gosline (1981). Such a condition is found among zeiforms and perciforms, such as certain cichlids and percoids. In particular, the premaxilla described here has a peculiarly narrow articular process, which might better be described as a maxillad spine as proposed by Barel et al. (1976) for the cichlid $\mathrm{Ha}$ plocromis elegans. Curiously enough, considering the antiquity of this fossil, the premaxilla described here shows greatest resemblance with the premaxilla of Haplocromis elegans among other acanthomorph fishes. They not only share the condition of the ascending and articular processes joined together in a single ascending arm, but also the ventral concavity of the dentigerous 
arm, and the peculiar characteristic of a very narrow articular process ending in a short and acute, but rounded portion, the maxillad spine. Other acanthomorphs with joined ascending and articular processes differ from this condition in that the relatively wide and dorsally rounded shape of the articular process, which is considered primitive, is either clearly recognizable (e.g., some scorpaeniforms, lutjanids, some sciaenids; Johnson 1980, Sasaki 1989, Yabe \& Uyeno 1996), or almost or completely lost (e.g., most zeiforms, nandids, congrogadines, other cichlids; Liem 1970, Rosen 1984, Godkin \& Winterbottom 1985, Casciotta \& Arratia 1993a, b).

Percomorpha Rosen, 1973

Perciformes Bleeker, 1859

Perciformes incertae sedis

\section{Saldenioichthys gen. nov.}

Type species: Saldenioichthys remotus sp. nov.
Diagnosis: As for type and only known species. Etymology: For the Saldeño Formation, the geological unit from which this fish was recovered, and the Greek ichthys for fish.

\section{Saldenioichthys remotus n. sp.}

Figs 4-5

Diagnosis: Although no autapomorphy can be identified in the only known specimen of Saldenioichthys remotus gen. et sp. nov., the species is diagnosed by the following unique combination of characters of the caudal skeleton: first preural centrum forming a single terminal centrum without independent ural centra; well developed, but short hypurapophysis between the haemal arch of the first preural centrum and the parhypural; five independent hypurals; fully developed neural spine of second preural centrum, which is longer than the preceeding ones and probably participates in the support of the fin rays; autogenous haemal arches of preural centra 2 and 3.

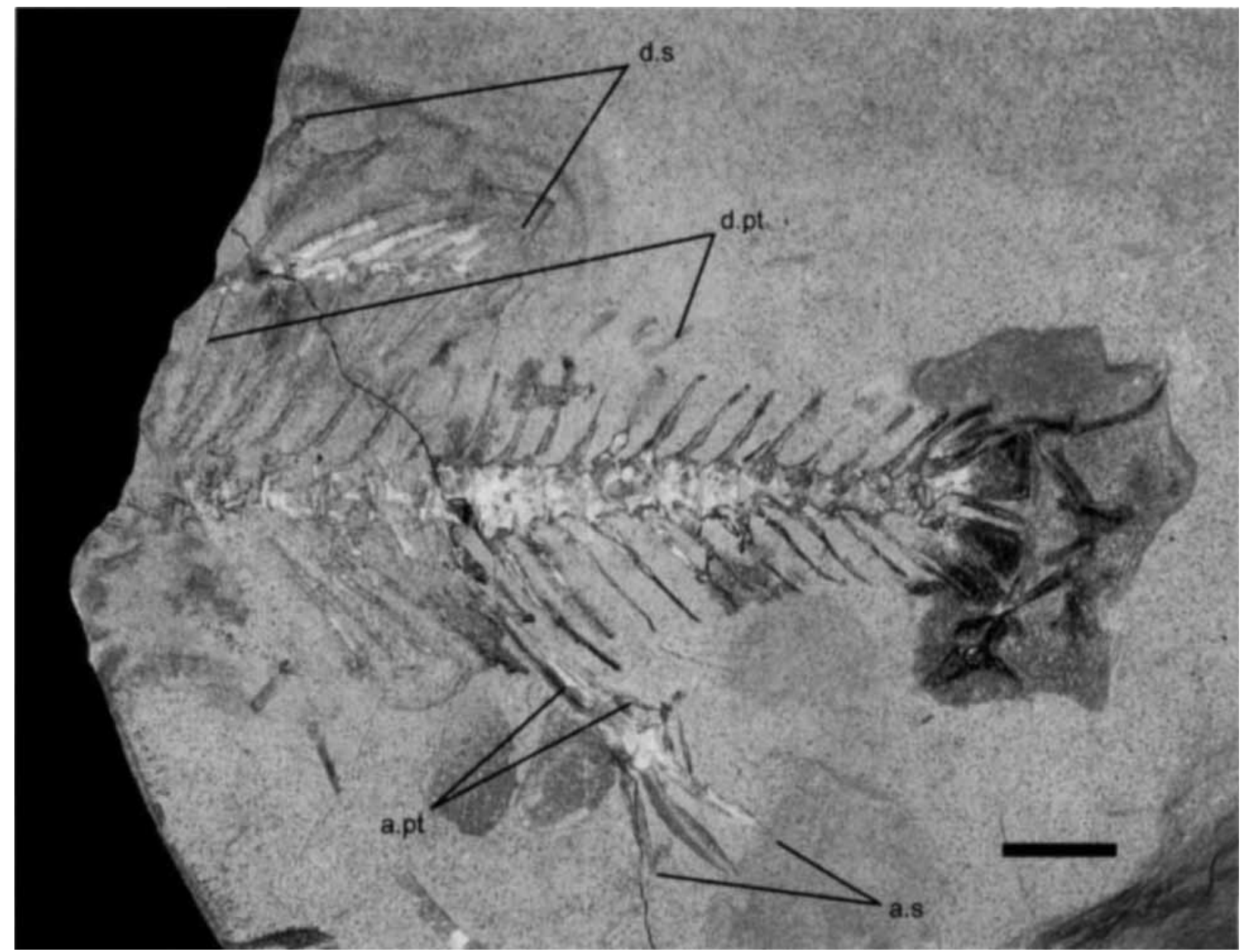

Fig. 4. Saldenioichthys remotus gen. et sp. nov. in lateral view (holotype, CPBA-V-14099). Abbreviations: a.pt, anal pterygiophores; a.s, anal spines; d.pt, dorsal pterygiophores; d.s, dorsal spines. Scale bar equals $10 \mathrm{~mm}$. 

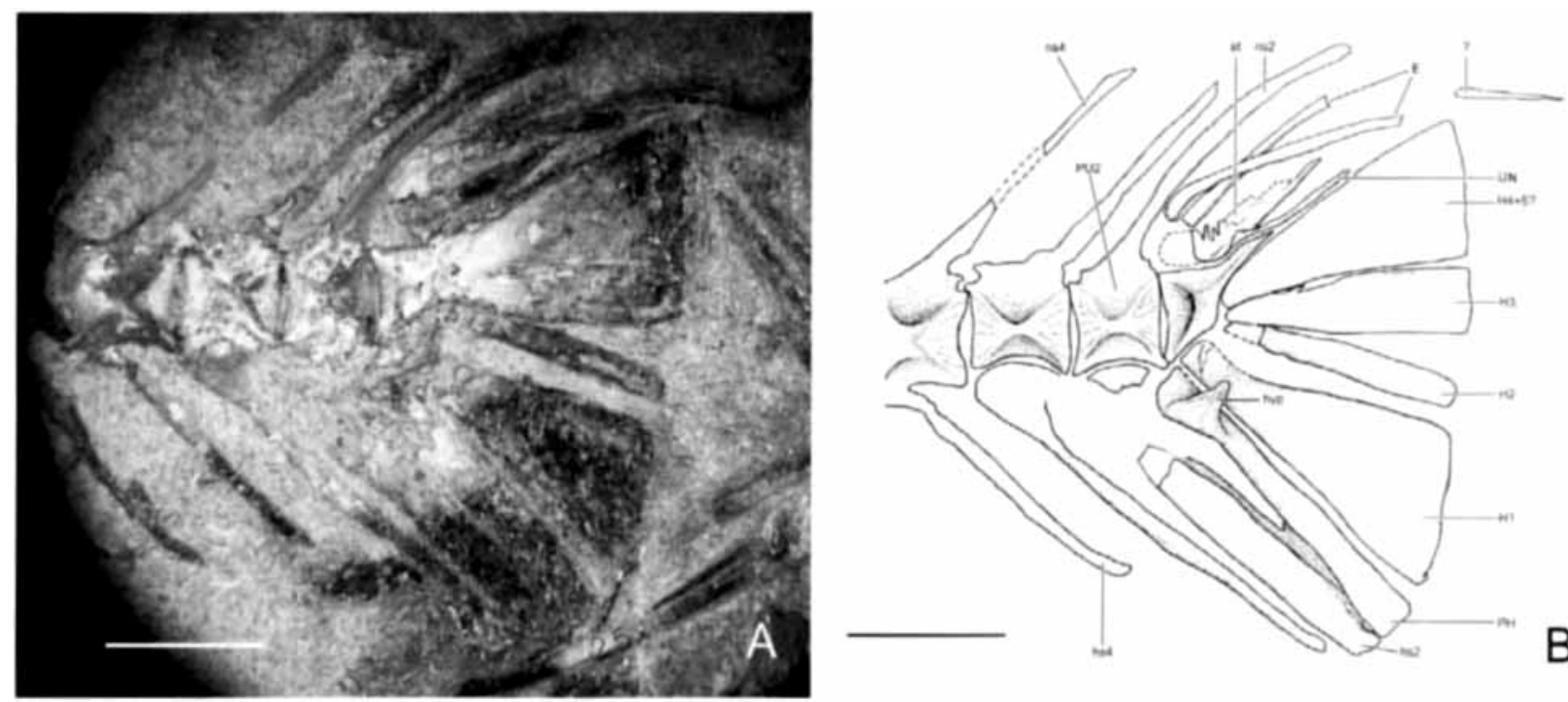

Fig. 5. Saldenioichthys remotus gen. et sp. nov. (holotype, CPBA-V-14099). Caudal fin skeleton. A. Photograph. B. Line drawing. Abbreviations: E, epurals; H1-3, hypural 1-3; H4 +5 ?, fused hypurals 4 and 5?; hs2, 4, haemal spine of the second and fourth preural centra; hyp, hypurapophysis; ns2, 4, neural spine of the second and fourth preural centra; PH, parhypural; PU2, second preural centrum; st, stegural (= uroneural); UN, uroneural; ?, third epural or uroneural? Scale bar equals $5 \mathrm{~mm}$.

Holotype: CPBA-V-14099: Posterior part of body, including the vertebral column and partially preserved dorsal and anal fins and caudal skeleton.

Horizon and locality: Calcareous sandstones in outcrops of the Saldeño Formation (Maastrichtian) at the Río Diamante site (W: $69^{\circ} 44^{\prime}$, S: $34^{\circ} 22^{\prime}$ ).

Etymology: Species name referring to the remote locality within the Saldeño Formation from where the specimen comes.

Description: The preserved part of the body of specimen CPBA-V-14099 is ca. $7.5 \mathrm{~cm}$ long. Considering the length of the preserved region and the possible length of the missing part, we assume that the fish was no more than $15 \mathrm{~cm}$ in standard length.

Vertebral column: Apart from the missing anteriormost vertebrae, six abdominal and 14 caudal vertebrae preserved (Fig. 4), including preural centrum 1 (PU1). Taking into consideration the position and number of dorsal finspines, we can assume that the fish had at least five or six more abdominal vertebrae giving an approximate minimun count of 25 vertebrae.

The abdominal centra are heavily ossified and seem to be longer than the first caudal vertebrae. The neural arches are positioned posterodorsal to the centra. The neural arches are stout, completely ossified and slightly inclined posteroventrally. A few, poorly preserved long ribs are displaced below the abdominal vertebral centra.
We interpret as first caudal vertebra the one bearing the left and right halves of the haemal arch joined medially and projecting in a ventral short and strong haemal spine. This first haemal spine lies posteriorly adjacent to the first anal pterygiophore (Fig. 4).

The caudal vertebrae have massive, strongly ossified centra with fused neural arches along the entire caudal region. In contrast, the last three haemal arches (belonging to preural centra $3-1$ ) are autogenous. All neural and haemal spines are slightly inclined toward the horizontal.

Dorsal fin: The dorsal fin (Fig. 4) is incompletely preserved and represented only by its spinous section. Although the soft rays are not preserved, some pterygiophores supporting them are present and they extend far posteriorly, opposite to the anal fin. Six spines are observed; the first one is represented by its distal tip and is of the same height, or probably slightly taller than the next spine. These two spines are the tallest; the following spines decrease in height caudally, and the last preserved spine is short and stout. According to the height of the first preserved spine, at least two or three spines might be missing at the beginning of the dorsal fin. A total of 12 pterygiophores are preserved and they decrease their size caudally. The pterygiophores of the spinous dorsal fin are wedgelike, with a longitudinal lateral ridge. The anteriormost three - and largest - pterygiophores reach close to the vertebral centra. In contrast, the succeding pterygiophores do not reach the 
tips of the neural spines. According to the number of ossified pterygiophores, al least seven soft rays were present.

Anal fin: The anal fin (Fig. 4) has three spines and an unknown number of soft rays. The first spine is the shortest and smallest and it is apparently supported in supernumerary association by the first pterygiophore. The second and third spines are almost of the same length and both are massive. The pterygiophores are badly preserved with the exception of the first two. The first pterygiophore is the largest, reaching close to the ventral face of the vertebral centra anterior to the first haemal spine, while the second pterygiophore is clearly thinner and shorter than the first.

Caudal skeleton: There are no fin-rays preserved so that the number of preural centra supporting fin rays cannot be properly established. The neural and haemal arches of preural centrum 4 and anteriormost vertebrae are fused to the autocentra; in contrast, the haemal arches of preural centra 3-1 are laterally unfused to their autocentra (Fig. 5A, B). The narrow neural spines of preural centra 4 and 3 are shorter than the neural spine of preural zentrum 2, which is the longest of the caudal region. The haemal spines of preural centra 4 and 3 are narrow, the spine of preural centrum 3 being longer than the anteriormost spines. The haemal spine of preural centrum 2 is broader and bears a posterior flange of membranous bone.

Preural centra 4 to 2 are strongly ossified; however, the base of the arches seems to retain cartilage medially. Preural centrum 1 seems to be represented by the anterior half of the centrum, and if there is any ural centrum fused to preural centrum 1 , there is no evidence for its presence. Because there is no ontogenetic evidence for the composition of this centrum, we prefer to simply identify it as terminal centrum. This terminal centrum projects dorsoposteriorly in an elongate acute process. The neural arch of preural centrum 1 is not as well developed as most anterior arches. An independent ural centrum - posterior to the terminal centrum - is absent, so that the last portion of the vertebral column is represented only by the terminal centrum.

The haemal arch of preural centrum 1 is autogenous and is slightly displaced anteriorly, lying below the intervertebral space. A well developed hypurapophysis for the insertion of the hypochordal longitudinalis muscle projects from the lateral wall between the parhypural and its arch.
The parhypural, or haemal spine 1 , is not as expanded as the haemal spine of preural centrum 2. There are four independent hypurals present. Because of their positions and sizes, the hypurals form a fan-like complex structure. The large hypural 1 is displaced slightly ventrally in the studied specimen. It broadens distally, being as large and broad as hypural $4+5(?)$. Hypural 2 is the narrowest element of the hypural series and is displaced slightly dorsally in the studied specimen. If hypurals 1 and 2 are placed in their normal position, it is obvious that the diastema between the ventral and dorsal hypurals is relatively broad. Hypural 3 is moderate in size, but larger than hypural 2. The dorsalmost element is very well developed and occupies the position that hypurals 4 and 5 have in other percomorphs. The single element does not show remnants of a suture line, so that it is unclear if this element is a compound hypural $4+5$ or only a single hypural 4 . If the latter alternative is correct, then hypural 5 is absent in this fish.

Dorsal to the terminal centrum there is an elongate, membrane-like uroneural, with an interdigitating dorsal margin, the so-called stegural. Laterally and slightly posteriorly placed is another uroneural, which it is narrow, elongated, and short, not reaching the level of the distal margin of the hypurals. No remnant of cartilage is observed in the uroneurals. Two long and narrow epurals are preserved. It is unclear if a displaced element, found posterior to the epurals and the hypural $4+5$ ?, is a fragment of a third epural or a third uroneural.

\section{Discussion}

The characteristics of the unpaired fins and especially the caudal fin skeleton of Saldenioichthys remotus gen. et sp. nov. indicate close phylogenetic relationships with perciform fishes. True dorsal and anal fin spines are only found within Acanthomorpha, and within this group the absence of a free second ural centrum in combination with five or fewer hypurals are only known in zeiforms, beryciforms (berycids and Tertiary and Recent holocentroids) and percomorphs (Johnson \& Patterson 1993). Although zeiforms also share a fully developed neural spine of preural centrum 2 with $S$. remotus gen. et sp. nov., they differ in other characters, such as no free uroneurals, fusion of hypurals, and second and third preural centra laterally fused to their haemal arches (Rosen 1984, Fujita 1990). Bery- 
PAGES MISSING FROM 169-172 